\title{
Seasonal Study for Habitat of Myriophyllum spicatum L. in Al-Burgga Marsh, Hor Al-Hammar, Southern Iraq
}

\author{
Mohammed A. H. Al-Kenzawi* \\ Received 24, February, 2014 \\ Accepted 4, May, 2014
}

\begin{abstract}
:
Myriophyllum spicatum distribution in Al-Burgga marsh, Hor Al-Hammar was described in relation to some of the physical-chemical properties for its habitat (water depth, light penetration, water temperature, water salinity, $\mathrm{pH}$, dissolved oxygen, $\mathrm{Ca}^{+2}, \mathrm{Mg}^{+2}$, reactive $\mathrm{NO}_{2}{ }^{=}$, reactive $\mathrm{NO}_{3}^{-1}$, and reactive $\mathrm{PO}_{4}^{-3}$ ) during 2011 , seasonally. CANOCO ordination program (CCA) was used to analyse the data. Its vegetation cover percentage was with its peak at summer, its value was $90 \%$, while the lowest value was $20 \%$ in winter. Statistically, Positive relationships for WT, sal., $\mathrm{Ca}^{+2}$, $\mathrm{Mg}^{+2}$, reactive $\mathrm{NO}_{2}=$, reactive $\mathrm{NO}_{3}^{-1}$, and reactive $\mathrm{PO}_{4}^{-3}$ with the vegetation cover percentage were observed. While, negative relationships for $\mathrm{WD}, \mathrm{pH}$, and $\mathrm{DO}$ with the vegetation cover percentage were observed. Also, the negative relationship between light penetration and the vegetation cover percentage can be attributed to the water depth, which was shallow and the light penetration followed water depth and reached to the bottom during all of the period study. In addition, two species were registered with Myriophyllum spicatum community as associated species, which are Hydrilla verticillata and Ceratophyllum demersum.
\end{abstract}

Key words: Myriophyllum spicatum. Habitat. Iraqi Marshes.

\section{Introduction:}

Myriophyllum spicatum originated in Europe, Asia, and Northern Africa [1]. Concern over the invasion of nonindigenous plants into natural areas is rapidly increasing, as the number of studies showing the prevalence and effects of such invasions rises [2,3] showed that the ability of alien plant species to invade a region depends not only on the attributes of the plants, but also on the characteristics of the invaded habitat. Aquatic plant habitat is threatened by changes in wetland hydrology, eutrophication, the invasion of exotic plants, and other humaninduced disturbances such as agriculture and development [4].

In Iraqi marshes, this species was identified for the firest time by [5] in Al-Suhein marsh, southern Iraq. Also, it was identified in the centeral marshes, southern Iraq by [6]. In Hor Al-Hammar, southern Iraq, this species was registered by [7]to study the epiphytic algae on it, but it was not registered in [8], which showed some notes on the ecology of aquatic plants in Al-Hammar marsh, southern Iraq. [9] observed that some of aquatic macrophytes in Al-Hammar marsh, southern Iraq are threatened by marine invasive creature, which is Balanus amphitrite, its existence was attributed to the variation within the marsh habitat.

Within the last few years, major hydrological engineering activities in and around the area of Lower Mesopotamia have resulted in the drying out of vast areas of wetlands in the Central Marches and Al-Hammar, and could eventually lead to the

*Biology Department, College of Science for Women, University of Baghdad. 
disappearance of these systems [10]. Currently, less than $10 \%$ of the marshlands in Iraq remain as fully functioning wetlands because of the extensive drainage and upstream agricultural irrigation programs on the Tigris and Euphrates rivers [11]. Now, restoration by re-flooding of drained marshes is proceeding in the Central and Al-Hammar marshlands [12].

One of these Iraqi marshes is AlBurgga marsh, southern Iraq, which is the largest part of Al-Hammar marsh, (figure -1-) which was destroyed by preventing water flow to it during 1990s by dams and applying the water regime for the water amounts, which reach to the south of Iraq. Then at 2003 , the restoration process of Iraqi marshes was started by removing the dams, which established on the Tigers and Euphrates Rivers, in addition to the increasing water amounts, which reach to southern areas from Iraq. So that the water reflooded to these areas and the life in these marshes started again, therefore, many flora Iraqi species disappeared, and at the same time, there are another species appeared and distributed, from them was Myriophyllum spicatum.

Myriophyllum spicatum was observed widely spread and covered large areas in Al-Burgga marsh, so that we decided to identify it, scientifically. In addition, to Study its habitat to know the environmental variables, which were available, that led to its growth and distribution in this marsh.

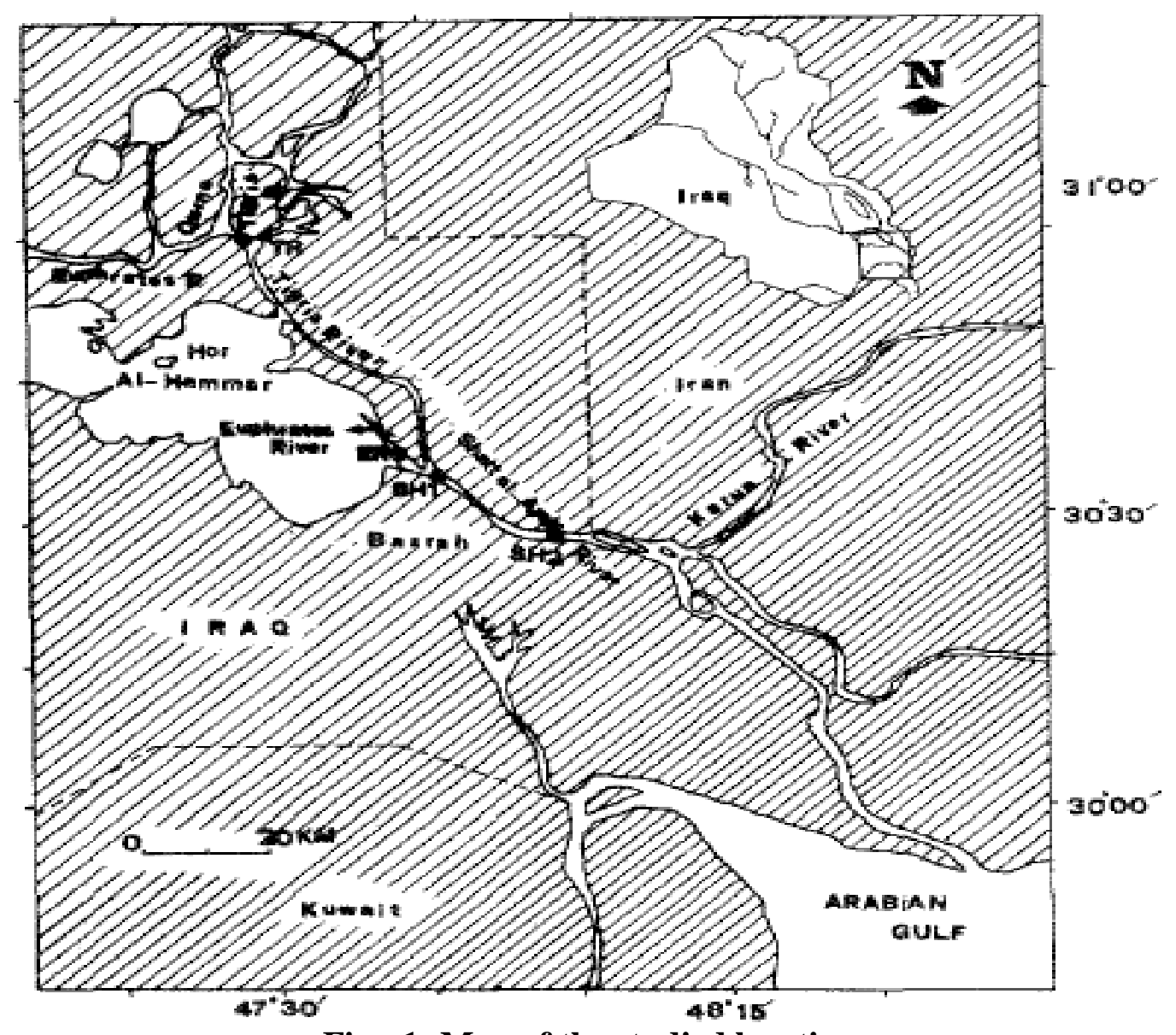

Fig. -1- Map of the studied location.

The marsh region is situated in the southern basin (alluvial plain) of the rivers Tigris and Euphrates at $30^{\circ} 35^{\prime}$ $32^{\circ} 45^{\prime} \mathrm{N}$ and $46^{\circ} 13^{\prime}-48^{\circ} \mathrm{E}$, with a 
maximum length of about $210 \mathrm{~km}$ and width of $170 \mathrm{~km}$. Its total area of about $35000 \mathrm{~km}^{2}$ is covered by water at the time of peak flood.

The daily mean temperature (30 years) is $12.4{ }^{\circ} \mathrm{C}$ in January and 33.9 ${ }^{\circ} \mathrm{C}$ in August. The annual rainfall varies from 84 to $296 \mathrm{~mm}$. The dry period is from June to October. Its area amounts to about $21 \%$ of the total marsh area in southern Iraq.

\section{Materials and Methods: Floristic Study}

The studied macrophyte species was identified in the herbarium of College of Science in the University of Basrah according to [13]. Vegetation Cover percentage is defined as the area of ground within the quadrate, which is occupied aboveground parts of each species when viewed from above. Cover was estimated usually as a percentage, the area of the quadrate is one $\mathrm{m}^{2}$ [14].

\section{Environmental variables}

The water environmental variables were measured according to [15]. Five water samples were taken at each season. The water temperature, water salinity, and water $\mathrm{pH}$ were measured directly in the field by digital portable multi meter (model 340i/SET, which is made in Germany), in addition the water depth by ironic ruler that is divided from $0-400 \mathrm{~cm}$ and light penetration by Secchi disk $(30 \mathrm{~cm}$ in diameter). Dissolved oxygen was measured by Azide-modification of Winkler method. Calcium and magnesium ions concentration were measured by titration against standard EDTA $(0.01 \mathrm{M})$. While, the nutrients $\left(\mathrm{NO}_{2}{ }^{-1}, \mathrm{NO}_{3}^{-1}\right.$, and $\left.\mathrm{PO}_{4}{ }^{-3}\right)$ were measured by coloremetric methods.

\section{Data analysis}

Mean and Standard Error for Water Environmental Variables were done. The computer program, which was used to analyze the data, it was
CANOCO [16] to apply Canonical Correspondence Analysis (CCA) method. This program provides ordination axes that maximally show the relationship between the species and the environmental because the ordination axes are constrained to be linear combination of environmental variables. As well as, (CCA) method shows the relationships between environmental variables to each other.

\section{Results:}

\section{Floristic Results}

The studied species was identified, which is Myriophyllum spicatum. Its vegetation cover percentage was measuered, seasonaly. The lowest value was at winter, when its vegetation cover percentage was $20 \%$. While, its growth reached to the peak at summer, its vegetation cover percentage was 90\%, see (figure -2-).

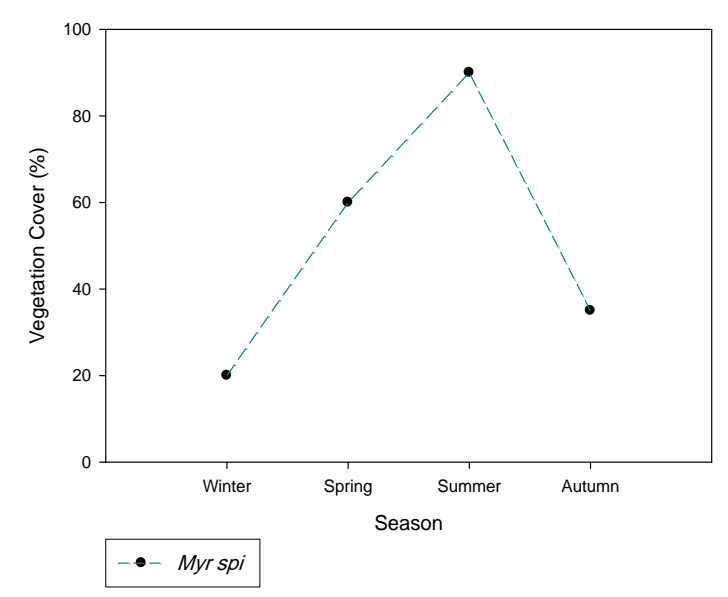

Fig.-2- Seasonal vegetation cover percentage for Myriophyllum spicatum.

\section{Environmental variables Results}

The environmental variables are clear in the followed figures down. Whereas the seasonal variation in the water depth value is clear, see (figure 3-), when the lowest level was at summer season $(57 \mathrm{~cm})$, while the highest level was at spring season (105 $\mathrm{cm})$. The light penetration reached to 
the bottom during all the study period, this is clear in the (figure-4-), it followed water depth, usually. The seasonal water temperature variations was clear, (figure -5-), when the lowest value was at winter $\left(9.75 \mathrm{C}^{\circ}\right)$, while the highest value was at summer $\left(26.65 \mathrm{C}^{\circ}\right)$. Salinity changed during the seasons, clearly, (figure -6-), its low value (2.7 ppt.) was at spring, while its high value (5.1 ppt.) was at summer season. The seasonal $\mathrm{pH}$ variations were clear, (figure -7-), when its low value (7.15) was at summer season, while the highest value (8.82) was at winter. Dissolved oxygen changed clearly during study period, (figure -8), when the lowest value $(2.2 \mathrm{mg} / \mathrm{l})$ was in summer, while the highest value (9.3 $\mathrm{mg} / \mathrm{l})$ was at winter. The seasonal variations for calcium and magnesium concentrations were clear, (figures -9and -10-), when their low values (105.9 $\mathrm{mg} / \mathrm{l}),(63.5 \mathrm{mg} / \mathrm{l})$ respectively were at spring, while their high values $(265.7$ $\mathrm{mg} / \mathrm{l}),(92.7 \mathrm{mg} / \mathrm{l})$, respectively were at autumn. The seasonal variations in nutrients concentrations $\left(\mathrm{NO}_{2}, \mathrm{NO}_{3}\right.$, and $\mathrm{PO}_{4}$ ) were clear during the study period, (figures -11-, -12-, and -13-), when their low values $(0.51 \mu \mathrm{g} / \mathrm{l})$, $(1.02 \mu \mathrm{g} / \mathrm{l})$, and $(0.93 \mu \mathrm{g} / \mathrm{l})$, respectively were at summer, while their high values $(1.66 \mu \mathrm{g} / \mathrm{l}),(3.39$ $\mu \mathrm{g} / \mathrm{l})$, and $(2.09 \mu \mathrm{g} / \mathrm{l})$, respectively were in winter.

These environmental variables were analyzed to know their means and standard errors, see (table -1-). As well as, the correlation ( $r$ ) between environmental variables to each other was done, it clear in the appendix -1-.

Table -1- Mean and Standard Error for Water Environmental Variables

\begin{tabular}{|c|c|c|c|c|c|c|c|c|c|c|c|}
\hline \multirow{2}{*}{ Season } & \multicolumn{11}{|c|}{ Mean and Standard Error for Water Environmental Variables } \\
\hline & WD $\pm S E$ & $\mathbf{L P} \pm \mathrm{SE}$ & $\mathrm{WT} \pm \mathrm{SE}$ & Sal. \pm SE & pH $\pm S E$ & DO \pm SE & $\mathrm{Ca} \pm \mathrm{SE}$ & Mg士SE & $\mathrm{NO}_{2} \pm \mathrm{SE}$ & $\mathrm{NO}_{3} \pm \mathrm{SE}$ & $\mathrm{PO}_{4} \pm \mathrm{SE}$ \\
\hline Winter & $92.5 \pm 6.5$ & $92.5 \pm 0$ & $9.75 \pm 0.24$ & $3.5 \pm 0$ & $8.82 \pm 0.03$ & $9.3 \pm 0.15$ & $194.2 \pm 13.12$ & $86.2 \pm 5.15$ & $1.66 \pm 0.11$ & $3.39 \pm 0.31$ & $2.09 \pm 0.04$ \\
\hline Spring & $105 \pm 4.7$ & $104 \pm 0$ & $11.75 \pm 0.15$ & $2.7 \pm 0$ & $8 \pm 0.1$ & $7.3 \pm 0.3$ & $105.9 \pm 8.29$ & $63.5 \pm 4.72$ & $0.87 \pm 0.06$ & $1.42 \pm 0.09$ & $1.21 \pm 0.09$ \\
\hline Summer & $57 \pm 3.5$ & $57 \pm 0$ & $26.65 \pm 0.55$ & $5.1 \pm 0$ & $7.15 \pm 0.05$ & $2.2 \pm 0.2$ & $172.2 \pm 11.06$ & $78.4 \pm 3.03$ & $0.51 \pm 0.09$ & $1.02 \pm 0.11$ & $0.93 \pm 0.05$ \\
\hline Autumn & $66.5 \pm 5.1$ & $66.5 \pm 0$ & $18.9 \pm 0.2$ & $4.7 \pm 0$ & $7.7 \pm 0$ & $4.9 \pm 0.4$ & $265.7 \pm 15.01$ & $92.7 \pm 5.57$ & $1.28 \pm 0.03$ & $2.99 \pm 0.02$ & $1.77 \pm 0.06$ \\
\hline
\end{tabular}

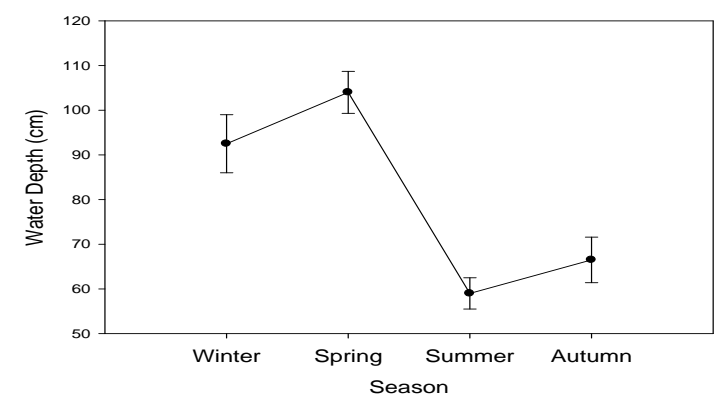

Fig.-3- Seasonal water depth variations with standard error.

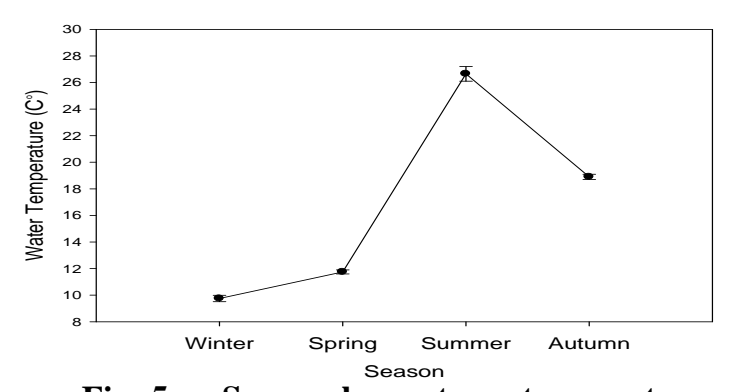

Fig.-5- Seasonal water temperature variations with standard error.

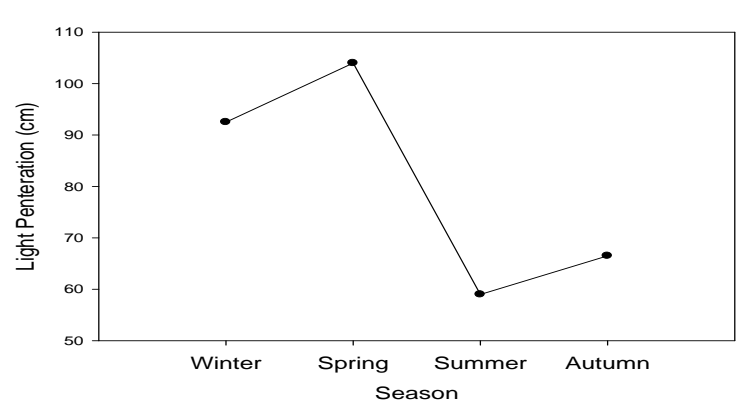

Fig.-4- Seasonal light penetration variations with standard error.

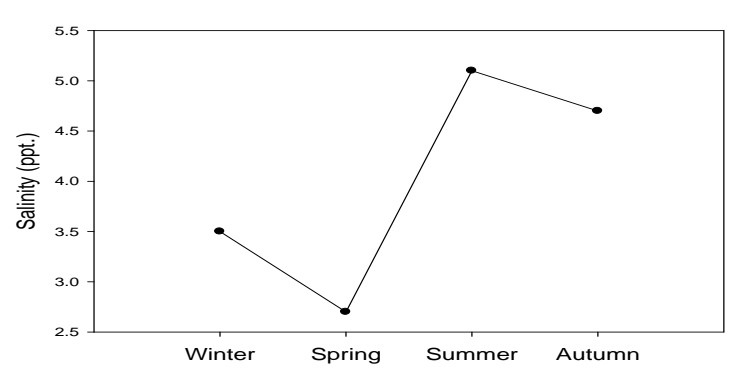

Fig.-6- Seasonal Seafinity variations with standard error. 


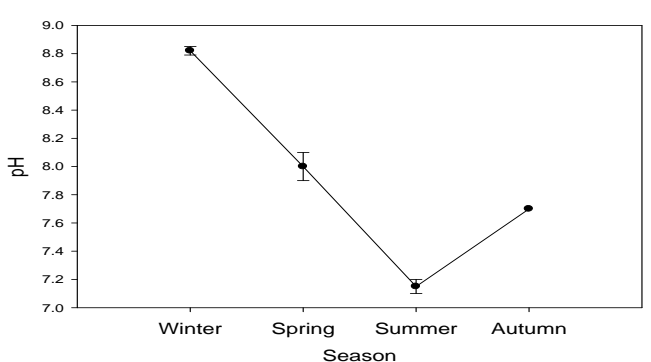

Fig.-7- Seasonal pH variations with standard error.

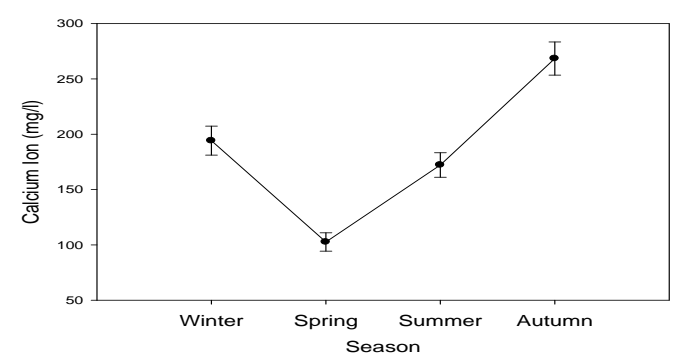

Fig.-9-Seasonal calcium ion concentration with standard error.

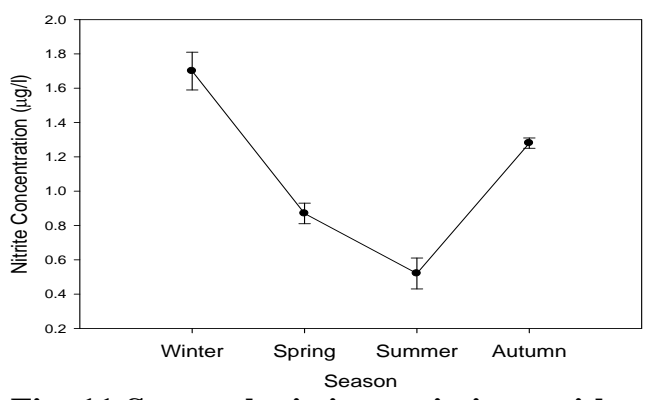

Fig.-11-Seasonal nitrite variations with standard error.

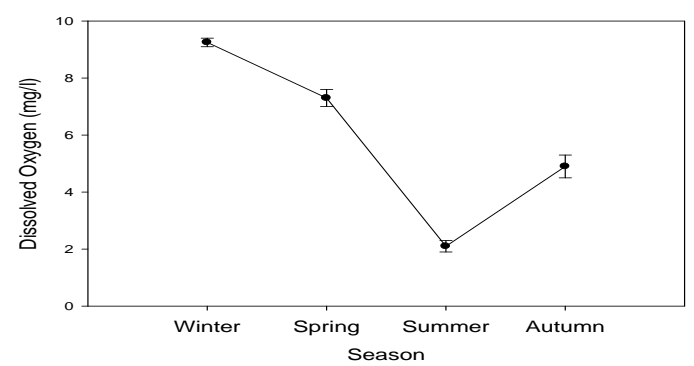

Fig.-8-Seasonal dissolved oxygen variations with standard error

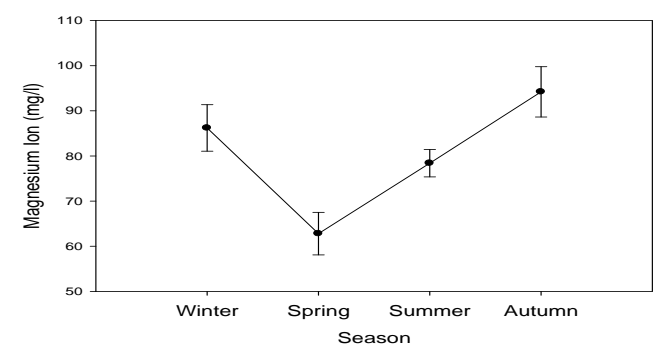

Fig.-10-Seasonal magnesium ion concentration with standard error.

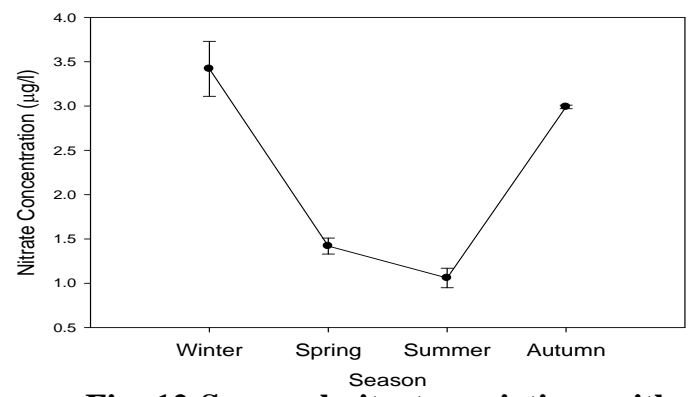

Fig.-12-Seasonal nitrate variations with standard error.

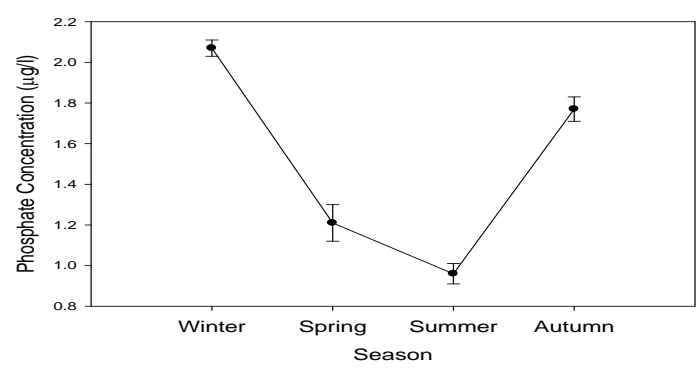

Fig.-13-Seasonal phosphate concentration variations with standard error.

Also, the relationships between environmental variables and species were concluded, statisticaly by CCA method, whereas positive relationships were observed between vegetation cover percentage for Myriophyllum spicatum and the values of water temperature, salinity, calcium ion, magnesium ion, reactive nitrate, reactive nitrite, and reactive phosphate. Their correlation (r) values were (0.853, 0.557, 0.939, 0.919, 0.746, 0.702 , and 0.663 ), respectively. While, negative relationships were observed between vegetation cover percentage for Myriophyllum spicatum and the values of the other environmental variables, which are water depth, $\mathrm{pH}$, 
and dissolved oxygen. Their correlation $(\mathrm{r})$ values were $(-0.980$, 0.624 , and -0.575$)$, respectively. On the other hand, light penetration reached to the bottom during the study period, totally. So that its correlation (r) value with vegetation cover percentage for Myriophyllum spicatum followed water depth, it was -0.980 . See figure -14- and appendix -1-.
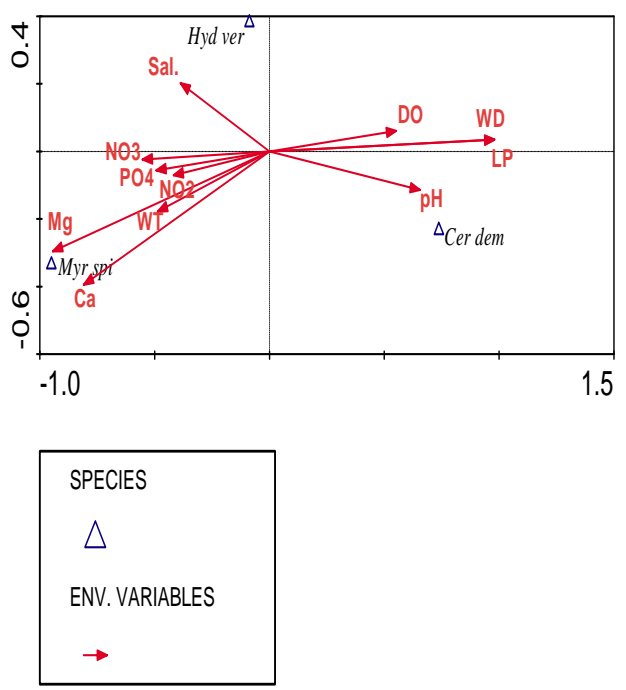

Fig. -14- The relationships between environmental variables and species by CCA method.

Note;

Myr spi= Myriophyllum spicatum, Cer dem $=$ Ceratophyllum dimerisum, Hye ver $=$ Hydrilla verticellata

\section{Discussion:}

The fluctuation in the growth of Myriophyllum spicatum in the present study may be due to the physical and chemical conditions for its habitat [17]. Its large distribution may be due to changing of the marsh ecological conditions after restoration that should be led to become appropriate habitat [18].

Myriophyllum spicatum growth was with its peak at summer that may be attribute to the environmental conditions should be changed to be more appropriate, while the environmental conditions are not suitable to growth of macrophytes at winter [18].

Water depth is one of the important ecological factors. In this study, the negative correlation between vegetation cover (\%) for Myriophyllum spicatum and water depth my be because the increasing of water depth leads to decreasing of light penetration to submerged aquatic plants, which affects the photosynthesis [19]. On the other hand the increasing of water level leads to dilute the nutrients which are required to growth of plants this agrees with [6,20,21]. Light penteration is very important factor for growth and distribution of the aquatic macrophyte, but this study showed there was negative correlation between light penteration and the growth that attribute to the water in the studied site was shallow so that light penetration followed water depth value and reached to the bottom during all the study period [6].

The positive relationship, which was observed between water temperature and vegetation cover $(\%)$ for Myriophyllum spicatum may be because the increasing of water temperature should enhance evapotranspiration, photosynthesis and microbial activity, the microbial organisms perform the degradation to dead bodies at warm season, so that the nutrients that are required by plants would be added to the ecosystem, so that temperature has positive effect on nutrients [21,22]. As well as, temperature affects chlorophyll content, whereas chlorophyll leaf concentration has positive correlation with temperature (chlorophyll concentration increases with increasing temperature) [23]. Also, the peak of vegetation cover (\%) for this species was at summer season, when the day lengths more than others seasons, whereas increasing day length at summer season should result 
increasing photosynthesis that should be led to more growth [23]. This agrees with $[6,20]$.

The positive effect for water salinity on the vegetation cover (\%) for Myriophyllum spicatum may be due to the indirect relationships between salinity and nutrients availability, that led for increasing growth of plant and reached to the peak at summer, when the salinity was in the highest value [22]. The results of the present study agree with [6.20], which found that the low salinity was alone resulted in reduced reproductive effort of macrophyte communities.

Calcium and Magnesium ions are essential nutrient for plants, whereas they share in structure of the cell wall and chlorophyll. The positive relationships between vegetation cover (\%) for Myriophyllum spicatum and these ions may be because these ions have effects on the microbial organisms, which performs the degradation for dead materials, that causes availability of nutrients which are required by aquatic plants, so that the growth of this species should be with the peak at the warm season (the growth season). These results agree with many studies [6,24,25]

Availability of nutrients is considered one of the main factors affecting the aquatic plants growth. Of the many nutrients required for growth, nitrogen $(\mathrm{N})$ and phosphorus $(\mathrm{P})$ are the elements typically of shortest supply in aquatic ecosystems and therefore most likely to affect the growth of aquatic macrophytes species [24].

The positive relationships between vegetation cover (\%) for Myriophyllum spicatum and and nutrients $\left(\mathrm{NO}_{2}^{-1}, \mathrm{NO}_{3}^{-1}\right.$, and $\left.\mathrm{PO}_{4}^{-3}\right)$ may be because the high growth requires big amounts from nitrogen and phosphorous compounds to metabolic processes [26].
Whereas, the nitrogen compounds are required by plants to share in protein structure, that should be led to increasing in the growth [24]. On the other hand, at winter and autumn, when there was no growth, there was no taking up for nitrogen compounds by plants, in addition, the concentrations that are added by the rain and the degradation process for the dead materials, so that their concentrations should be increased at these seasons $[6,21,26]$

The same case for phosphate concentration, its positive effect on vegetation cover (\%) for Myriophyllum spicatum may be because it is important for plants; it shares in structure of the cell wall, protein, nucleotide and ATP [27]. This result agrees with [6,22].

Many studies have found that $\mathrm{pH}$ has important influence on aquatic plants growth and distribution $[6,22,26]$. In this study, the negative correlation between $\mathrm{pH}$ value and vegetation cover (\%) for Myriophyllum spicatum may be because that $\mathrm{pH}$ is affected by dissolved inorganic carbon, which is available for photosynthesis [22]. As well as, the variations in dissolved inorganic carbon availability may account for differences in the growth and distribution of Myriophyllum spicatum among low and high dissolved inorganic carbon locations [26]. This result agrees with many studies $[6,22,24]$

The negative correlation between dissolved oxygen concentration and vegetation cover (\%) for Myriophyllum spicatum may be because gas exchange between the atmosphere and surface water during the growth season (summer) is controlled primarily by the gas concentration gradient and the boundary layer thickness [24]. As well as, aquatic macrophytes produce structural material (lignin, cellulose, and hemicelluloses), and this material 
decomposes relatively slowly, and at that time the microbial organisms consume more dissolved oxygen during the degradation process for these materials during the growth season, so that the dissolved oxygen will be decreased, and inverse this case at the winter season, this agrees with many studies $[6,25,26]$.

Appendix -1- The correlation ( $r$ ) between environmental variables and vegetation cover (percentage) for Myriophyllum spicatum. Also, between environmental variables to each other.

\begin{tabular}{|c|c|c|c|c|c|c|c|c|c|c|c|c|}
\hline & WD & LP & WT & Sal. & pH & DO & Ca & Mg & NO3 & NO2 & PO4 & Myr spi \\
\hline WD & 1.000 & & & & & & & & & & & \\
\hline LP & 1.000 & 1.000 & & & & & & & & & & \\
\hline WT & -0.378 & -0.378 & 1.000 & & & & & & & & & \\
\hline Sal. & 0.026 & 0.026 & 0.824 & 1.000 & & & & & & & & \\
\hline pH & 0.480 & 0.480 & -0.922 & -0.864 & 1.000 & & & & & & & \\
\hline DO & 0.708 & 0.708 & -0.986 & -0.869 & 0.973 & 1.000 & & & & & & \\
\hline Ca & -0.934 & -0.934 & 0.544 & -0.085 & -0.403 & -0.413 & 1.000 & & & & & \\
\hline Mg & -0.961 & -0.961 & 0.503 & -0.247 & -0.270 & -0.236 & 0.969 & 1.000 & & & & \\
\hline NO3 & -0.379 & -0.379 & 0.977 & 0.894 & -0.979 & -0.998 & 0.369 & 0.195 & 1.000 & & & \\
\hline NO2 & -0.153 & -0.153 & 0.960 & 0.945 & -0.912 & -0.965 & 0.181 & -0.020 & 0.971 & 1.000 & & \\
\hline PO4 & -0.285 & -0.285 & 0.980 & 0.918 & -0.955 & -0.991 & 0.297 & 0.108 & 0.994 & 0.991 & 1.000 & \\
\hline Myr spi & $\mathbf{- 0 . 9 8 0}$ & $\mathbf{- 0 . 9 8 0}$ & $\mathbf{0 . 8 5 3}$ & $\mathbf{0 . 5 5 7}$ & $\mathbf{- 0 . 6 2 4}$ & $\mathbf{- 0 . 5 7 5}$ & $\mathbf{0 . 9 3 9}$ & $\mathbf{0 . 9 1 9}$ & $\mathbf{0 . 7 4 6}$ & $\mathbf{0 . 7 0 2}$ & $\mathbf{0 . 6 6 3}$ & $\mathbf{1 . 0 0 0}$ \\
\hline
\end{tabular}

\section{References:}

1. Cronk, J.K. and Fennessy, M.S. 2001. Wetland Plants Biology and Ecology. CRC Press LLC. 462 pp.

2. Thompson, J.D. 1991. The biology of an invasive plant. J. of Bio Sci., 41: 393- 400.

3. Larson, D.L., Patrick, J.A., Newton, W. 2001. Alien plant invasion in mixed-grass prairie: effects of vegetation type and anthropogenic disturbance. $J$. Ecol. Appl., 11: 128-141.

4. Wishueu, I. C. and Keddy, P.A. 1994. The low competitive ability of Canada's Atlantic costal plain shoreline flora: implications for conservation. J. Bio. Cons., 68: 247-252.

5. Al-Hilli, M.R. 1977. Studies on the plant ecology of Ahwar region in Southern Iraq. Ph.D. Thesis, Fac. Sci. Univ. Cairo, Egypt. 477 pp.
6. Al-Kenzawi, M. A. H. 2007. Ecological study of aquatic macrophytes in the central part of the marshes of Southern Iraq. Baghdad University-College of Science for Women, Iraq, pp. 270.

7. Al-Lami, A.A. 1986. An ecological study on the phytoplankton Southern Iraq. M.Sc. Thesis, College of Science, University of Basrah, Iraq. 136 pp.

8. A1-Kenzawi, M. A. H., Hassan, F. M. and Al-Mayah, A. A. A. 2012. The Distribution of Ceratophyllum demersum L. in Relation to Environmental Factors in Restored Al-Mashb Marsh, Hor AlHammar, Southern Iraq. Mar. Bull., 7(2): 137-149.

9. Jawair, H.J. and Al-Kenzawi, M. A. 2009. Settled Barnacles Balanus amphitrite threat emergent macrophyte in AlHammar marshes, Iraq. J. of F.B.A. News. Spring 2009. 
10. Richardson, C.J., Reiss, P., Hussain, N.A., Alwash, A.J., Pool, D.J. 2005. The restoration of potential of the Mesopotamian marshes of Iraq. J. Sci., 307:13071311.

11. Partow, H. 2001. Demise of an ecosystem: the disappearance of the Mesopotamian Marshlands United Nations Environment Program (UNEP). Publication UNEP/DEWA/TR. 01-3, Nairobi, Kenya.

12. Lawler, A. 2005. Reviving Iraq's wetlands. J. Sci., 307:1186-1189.

13. Prescott, G.W. 2001. How to Know the Aquatic Plants; The Pictured Key Nature Series, 3rded. WM.C. Brown Co., Dubuque, Iowa, $177 \mathrm{pp}$.

14. Kent, M. and Coker, P. 1992. Vegetation description and analysis: a practical approach. Printed and bound in Great Britain by Short Run Press, Exeter. Pp363.

15. APHA, AWWA, WPCF 2003. Standard methods for the examination of water and wastewater. 14th ed. American public Health Association, Washington, DC.

16. Ter Braak, C.J.F. 1986. Canonical Correspondence Analysis: A new eigenvector technique for multivariate direct gradient analysis. J. Eco., 67: 1167-1179.

17. Menzie, C. A. 1979. Growth of the aquatic plant Myriophyllum spicatum in a littoral area of the Hudson River Estuary. J. Aqu. Bot., 6: 365-375.

18. Williamson, M. 1999. Invasions. J. of Ecogra., 22: 5-12.

19. Terrados, J., Grau-Castella, M., Pinol-Santina, D. and Riera- Fernandez, $\quad$ P. 2006. Biomass and Primary Production of a $8-11 \mathrm{~m}$ Depth Meadow Versus $<3 m$ Depth Meadows of
Seagrass Cymodocea nodosa (Ucria) Ascherson. J. Aqu. Bot., 84: 324-332.

20. Herb, W.R. and Stefan, H.G. 2006. Seasonal growth of submersed macrophytes in lakes: The effects of biomass density and light competition. J. Eco. Modell., 193: 560-574.

21. Al-Kenzawi, M.A.H. 2009. Seasonal Changes of Nutrient Concentrations in Water of Some Locations in Southern Iraqi Marshes, After Restoration. $J$. Um-Sala. for Sci., 6(4): 711-718.

22. Heegaard, E., Birks, H.H., Gibson, C.E., Smith, S.J. and WolfeMurphy, S. 2001. Speciesenvironmental relationships of aquatic macrophytes in Northern Ireland. J. Aqu. Bot., 70: 175-223.

23. Spencer, D. and Ksander, G. 1991. Influence of temperature and light on early growth of Potamogeton gramineus L.. J. Fresh. Eco., 6: 227-235.

24. Serag, M.S. and Khedr, A.A. 2001. Vegetation-environment relationships along El-Salam Canal, Egypt. J. Env., 12: 219232.

25. Al-Kenzawi, M.A.H. and AlRawi, A.A. 2009. The Role of Emergent Aquatic Macrophytes in Changing Water Quality at AlShafi Marsh, Southern Iraq. J. Cen. of Biotec. Res.., 3(1): 176187.

26. Khedr, A.H.A. and El-Demerdash, M.A. 1997. Distribution of aquatic plants in relation to environmental factors in the Nile Delta. J. Aqu. Bot., 56: 75-86.

27. Ashihara, H., Li, X.N. and Ukaji, T. 1988. Effect of inorganic phosphate on the biosynthesis of purine and pyrimidine nucleotides in the suspension-cultured cells of Catharanthus roseus. J. Anal. Bot., 61:225-232. 


\section{دراسة موسمية لبيئة نبات ال .Myriophyllum spicatum L في هور البركة البرات

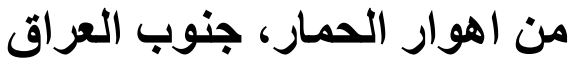 \\ محمد عبدالرضا حمدان الكنزاوي*}

*قسم علوم الحياة- كلية العلوم للبنات- جامعة بغداد

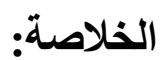

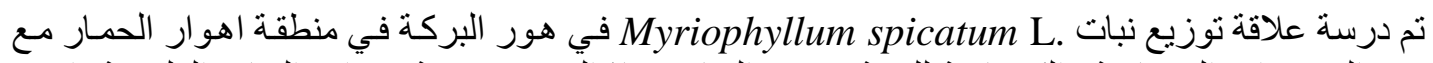

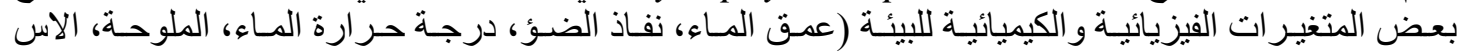

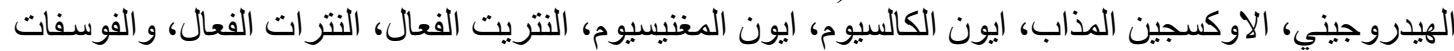

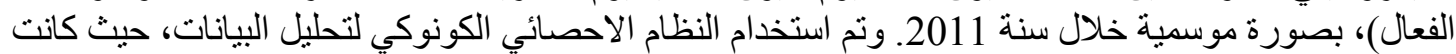

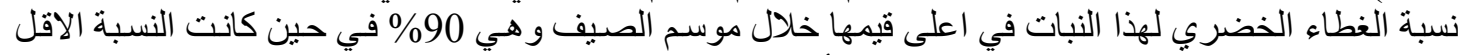

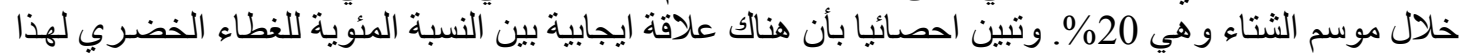

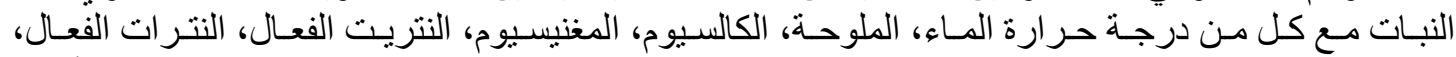

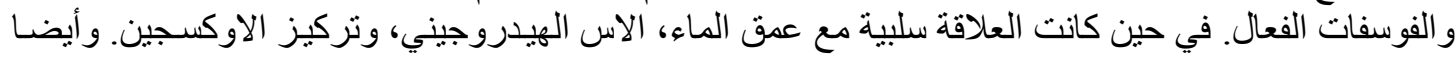

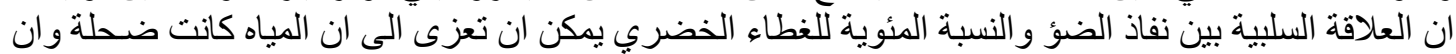

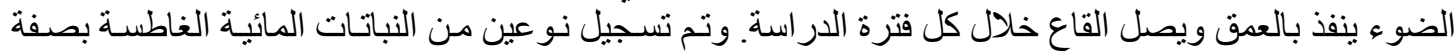

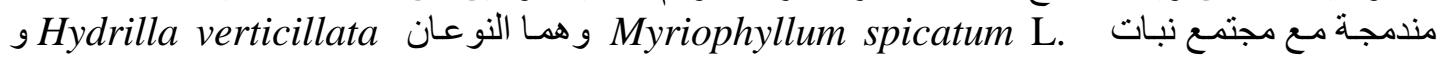

.Ceratophyllum demersum 